\title{
SOME FUNDAMENTAL LEGAL CONCEPTIONS AS APPLIED IN JUDICIAL REASONING
}

- From very early days down to the present time the essential nature of trusts and other equitable interests has formed a favorite subject for analysis and disputation. The classical discussions of Bacon ${ }^{1}$ and Coke are familiar to all students of equity, and the famous definition of the great chief justice (however inadequate it may really be) is quoted even in the latest textbooks on trusts. ${ }^{2}$ That the subject has had a peculiar fascination for modern legal thinkers is abundantly evidenced by the well known articles of Langdell ${ }^{3}$ and Ames, ${ }^{4}$ by the oft-repeated

1 Bacon on Uses (Circa 1602; Rowe's ed. 1806), pp. 5-6: "The nature of an use is best discerned by considering what it is not, and then what it is. *** First, an use is no right, title, or interest in law; and therefore master attorney, who read upon this statute, said well, that there are but two rights: Jus in re: Jus ad rem.

"The one is an estate, which is jus in re; the other a demand, which is jus ad rems but an use is neither. *** So as now we are come by negatives to the affirmative, what an use is. ***Usus est dominium fiduciarium: Use is an ownership in trust.

"So that usus \& status, sive possessio, potius differunt secundum rationem fori, quam secundum naturam rei, for that one of them is in court of law, the other in court of conscience. ***"

2.Co. Lit. (1628) $272 \mathrm{~b}$ : "Nota, an use is a trust or confidence reposed in some other, which is not issuing out of the land, but as a thing collaterall, annexed in privitie to the estate of the land, and to the person touching the land, scilicet, that cesty que use shall take the profit, and that the terre-tenant shall make an estate according to his direction. So as cesty que use had neither jus in re, nor jus ad rem, but only a confidence and trust for which he had no remedie by the common law, but for the breach of trust, his remedie was cnly by subpoena in chancerie.

This definition is quoted and discussed approvingly in Lewin, Trusts (12th ed., 1911), p. 11. It is also noticed in Maitland, Lectures on Equity (1909), pp. 43, 116.

3 See Langdell, Classification of Rights and Wrongs (1900), 13 Harv. L. Rev., 659, 673: "Can equity then create such rights as it finds to be necessary for the purposes of justice? As equity wields only physical power, it sems to be impossible that it should actual'y create anything. $* * *$ It seems, therefore, that equitable rights exist only in contemplation of equity, i.e., that they are a fiction invented by equity for the promotion of justice. $* * *$

"Shutting cur eyes, then, to the fact that equitable rights are a fiction, and assuming them to have an actual existence, what is their nature, what 
observations of Maitland in his Lectures on Equity, ${ }^{5}$ by the very divergent treatment of Austin in his Lectures on Jurisprudence, ${ }^{8}$ by the still bolder thesis of Salmond in his volume on Jurisprudence, $^{7}$ and by the discordant utterances of $\mathrm{Mr}$. Hart ${ }^{8}$ and $\mathrm{Mr}$.

their extent, and what is the field which they occupy? *** They must not violate the law. $* * *$ Legal and equitable rights must, therefore, exist side by side, and the latter cannot interfere with, or in any manner affect, the former."

See also (1887) 1 Harv. L. Rev., 55, 60: "Upon the whole, it may be said that equity could not create rights in rem if it would,. and that it would not if it could." Ccmpare Ibid. 58; and Summary of Eq. Plead. (2nd ed., 1883) secs. 45, 182-184.

4 See Ames, "Purchase for Value Without Notice" (1887), 1 Harv. L. Rev., 1, 9: "The trustee is the owner of the land, and, of course, two persons with adverse interests cannot be owrers of the same thing. What the cestui que trust really owns is the obligation of the trustee; for an ob'igation is as truly the subject matter of property as any physical res. The most striking difference between property in a thing and property in an obligation is in the mode of enjoyment. The owner of a house or a horse enjoys the fruits of ownership without the aid of any other person. The only way in which the cwner of an obligation can realize his ownership is by compelling its performance by the obl'gor. Herce, in the one case, the owner is said to have a right in rem, and in the other, a right in pcrsonam. In other respects the common rules of property apply equally to ownership of things and ownership of obligations. For example, what may be called the passive rights of ownership are the same in both cases. The general duty resting on all mankind not to destroy the property of another, is as cogent in favor of an obligee as it is in favor of the owner of a horse. And the violation of this duty is as pure a tort in the one case as in the other."

"Lect. on Eq. (1909), 17, 18, 112: "The thesis that I have to maintain is this, that equitable estates and interests are not jura in rent. For reasons that we shall perceive by and by, they have come to look very like jura in rem; but just for this very reason it is the more necessary for us to observe that they are essentially jura in personam, not rights against the world at large, but rights against certain persons."

See also Maitland, Trust and Corporation (1904), reprinted in 3 Collected Papers, 321, 325.

${ }^{6}$ (5th ed.) Vol. I, p. 378: "By the provisions of that part of the English law which is calfed equity, a contract to sell at once vests $j u s$ in rem or ownership in buyer, and the seller has only jus in re aliena. * * * To complete the transaction the legal interest of the seller must be passed to the buyer, in legal form. To this purpose the buyer has only jus in personam: a right to compel the seller to pass his legal interest; but speaking generally, he has dominium or jus in rem, and the instrument is a conveyance."

7 (2nd ed., 1907) p. 230: "If we have regard to the essence of the matter rather than to the form of it, a trustee is not an owner at all, but 
Whitlock ${ }^{9}$ in their very recent contributions to our periodical literature.

It is believed that all of the discussions and analyses referred to are inadequate. Perhaps, however, it would have to be admitted that even the great intrinsic interest of the subject itself and the noteworthy divergence of opinion existing among thoughtful lawyers of all times would fail to afford more than a comparatively slight excuse for any further discussion considered as a mere end in itself. But, quite apart from the presumably practical consideration of endeavoring to "think straight" in relation to all legal problems, it is apparent that the true analysis of trusts and other equitable interests is a matter that should appeal to even the most extreme pragmatists of the law. It may well be that one's view as to the correct analysis of such interests would control the decision of a number of specific questions. This is obviously true as regards the solution of many difficult and delicate problems in constitutional law and in the conflict of laws. ${ }^{10}$ So, too, in certain questions in the law of perpetuities, the intrinsic nature of equitable interests is of great significance, as attested

a mere agent, upon whom the law has conferred the power and imposed he duty of administering the property of another person. In legal theory, however, he is not a mere agent, but an owner. He is a person to whom the property of sameone else is fictitiously attributed by the law, to the intent that the rights and powers thus rested in a nominal owner shall be used by him on behalf of the real owner."

$s$ See Walter G. Hart (author of "Digest of Law of Trusts"), The Place of Trust in Jurisprudence (1912), 28 Law Quart. Rev., 290, 296. His position is substantially that of Ames and Maitland.

At the end of this article Sir Frederick Pollock, the editor, puts the query: "Why is Trust not entitled to rank as a head sui generis?"

${ }^{9}$ See A. N. Whitlock, Classification of the Law of Trusts (1913), 1 Calif. Law Rev., 215, 218: "It is submitted," says the writer, "that the cestui has in fact something more than a right in personam, that such a right might be more properly described as a right in personam ad rem, or, possibly, a right in rem per personam."

Surely such nebulous and cumbreus expressions as these could hardly fail to make "confusion worse confounded."

10 See Beale, Equitable Interests in Foreign Property, 20 Harv. L. Rev. (1907), 382; and compare the important cases, Fall v. Eastin (1905), 75 Neb., 104; S. C. (1909), 215 U. S., 1, 14-15 (especially concurring opinion of Holmes, J.) ; Selover, Bates \& Co. v. Walsh (1912), 226 U. S., 112; Bank of Africa Limited v. Cohen (1909), 2 Ch. 129, 143. 
by the well-known Gomm case ${ }^{11}$ and others more or less similar. The same thing is apt to be true of a number of special questions relating to the subject of bona fide purchase for value. So on indefinitely. ${ }^{12}$

But all this may seem like misplaced emphasis; for the suggestions last made are not peculiarly applicable to equitable interests: the same points and the same examples seem valid in relation to all possible kinds of jural interests, legal as well as equitable,-and that too, whether we are concerned with "property," "contracts," "torts," or any other title of the law. Special reference has therefore been made to the subject of trusts and other equitable interests only for the reason that the striking divergence of opinion relating thereto conspicuously exemplifies the need for dealing somewhat more intensively and systematically than is usual with the nature and analysis of all types of jural interests. Indeed, it would be virtually impossible to consider the subject of trusts at all adequately without, at the very threshold analyzing and discriminating the various fundamental conceptions that are involved in practically every legal problem. In this connection the suggestion may be ventured that the usual discussions of trusts and other jural interests seem inadequate (and at times misleading) for the very reason that they are not founded on a sufficiently comprehensive and discriminating analysis of jural relations in general. Putting the matter in another way, the tendency-and the fallacy-has been to treat the specific problem as if it were far less complex than it really is; and this commendable effort to treat as simple that which is really complex has, it is believed, furnished a serious obstacle to the clear understanding, the orderly statement, and the correct solution of legal problems. In short, it is submmitted that the

11 (1882) 20 Ch. D. 562, 580, per Sir George Jessel, M. R.: "If then the rule as to remoteness applies to a covenant of this nature, this covenant clearly is bad as extending beyond the period allowed by the rule. Whether the rule applies or not depends upon this, as it appears to me, does or does not the covenant give an interest in the land? *** If it is a mere personal contract it cannot be enforced against the assignee. Therefore the company must admit that somehow it binds the land. But if it binds the land, it creates an equitable interest in the land.".

12 Compare Ball v. Milliken (1910), 31 R. I., 36; 76 Atl., 789, 793, involving a point other than perpetuities, but quoting in support of the decision reached Sir George Jessel's language as to "equitable interests in land." See preceding note. 
right kind of simplicity can result only from more searching and more discriminating analysis.

If, therefore, the title of this article suggests a merely philosophical inquiry as to the nature of law and legal relations,-a discussion regarded more or less as an end in itself,- - the writer may be pardoned for repudiating such a connotation in advance. On the contrary, in response to the invitation of the editor of this journal, the main purpose of the writer is to emphasize certain oft-neglected matters that may aid in the understanding and in the solution of practical, every-day problems of the law. With this end in view, the present article and another soon to follow will discuss, as of chief concern, the basic conceptions of the law,-the legal elements that enter into all types of jural interests. A later article will deal specially with the analysis of certain typical and important interests of a complex character,-more particularly trusts and other equitable interests. In passing, it seems necessary to state that both of these articles are intended more for law school students than for any other class of readers. For that reason, it is hoped that the more learned reader may pardon certain parts of the discussion that might otherwise seem unnecessarily elementary and detailed. On the other hand, the limits of space inherent in a periodical article must furnish the excuse for as great a brevity of treatment as is consistent with clearness, and for a comparatively meager discussion-or even a total neglect-of certain matters the intrinsic importance of which might otherwise merit greater attention. In short, the emphasis. is to be placed on those points believed to have the greatest practical value.

\section{LEGAL CONCEPTIONS CONTRASTED WITH NON- LEGAL CONCEPTIONS.}

At the very outset it seems necessary to emphasize the importance of differentiating purely legal relations from the physical and mental facts that call such relations into being. Obvious as. this initial suggestion may seem to be, the arguments that one may hear in court almost any day and likewise a considerable number of judicial opinions afford ample evidence of the inveterate and unfortunate tendency to confuse and blend the legal and the nonlegal quantities in a given problem. There are at least two special reasons for this. 
For one thing, the association of ideas involved in the two sets of relations-the physical and the mental on the one hand, and the purely legal on the other-is in the very nature of the case, extremely close. This fact has necessarily had a marked influence upon the general doctrines and the specific rules of early syslıms of law. Thus, we are cold by Pollock and Maitland:

"Ancient German law, like ancient Roman law, sees great difficulties in the way of an assignment of a debt or other banefit of a contract $* * *$ men do not see how there can be a transfer of a right unless that right is embodied in some corporeal thing. The history of the incorporeal things has shown us this; they are not completely transferred until the transferee has obtained seisin. has turned his beasts onto the pasture, presented a clerk to the church or hanged a thief upon the gallows. A covenant or a warranty of titl? may be so bound up with land that the assignee of the land will be able to sue the covenantor or warrantor."1s

In another connection, the same learned authors observe:

"The realm of medirval law is rich with incorporeal things. Any permanent right which is of a transferable nature, at all events if it has what we may call a territorial ambit, is thought of as a thing that is very like a piece of land. Just bicause it is a thing it is transferab!e. This is no fiction invented by the speculative jurists. For the popular mind these things are things. The lawyer's business is not to make them things but to point out that they are incorporcal. The layman who wishes to convey the advowson of a church will say that he conveys the church; it is for Bracton to explain to him that what he means to transfer is not that structure of wood and stone which belongs to God and the saints. but a thing incorporeal, as incorporeal as his own soul or the anima mundi."14

A second reason for the tendency to confuse or blend non-legal and legal conceptions consists in the ambiguity and looseness of our legal terminology. The word "property" furnishes a striking example. Both with lawyers and with laymen this term has no definite or stable connotation. Sometimes it is employed to indicate the physical object to which various legal rights, privileges, etc., relate; then again-with far greater discrimination and accuracy-the word is used to clenote the legal interest (or aggregate of legal relations) appertaining to such physical object. Frequently there is a rapid and fallacious shift from the one

132 Hist. Eng. Law (2nd ed., 1905), 226.

14 Ibid., 124. 
meaning to the other. At times, also, the term is used in such a "blended" sense as to convey no definite meaning whatever.

For the purpose of exemplifying the looser usage just referred to, we may quote from Wilson v. Ward Lumber Co.:15

“The term 'property', as commonly used denotes any external cbject over which the right of property is exercised. In this sense it is a very wide term, and includes every class of acquisitions which a man can own or have an interest in."

Perhaps the ablest statement to exemplify the opposite and more accurate usage is that of Professor Jeremiah Smith (then Mr. Justice Smith) in the leading case of Eaton v. B. C. \& $M$. R. R. Co.: $:^{16}$

'In a strict legal sense, land is not 'property', but the subject of propsrty. The term 'property', although in common parlance frequently applied to a tract of land or a chattel, in its legal signification 'means only the rights of the owner in relation to it'. 'It denotes a right over a determinate thing'. 'Property is the right of any person to possess, use, enjoy, and dispose of a thing'. Selden, J., in Wynehamer v. People, 13 N. Y., 378, p. 433; 1 Blackstone's com., 138; 2 Austin's Jurisprudence, 3rd ed., 817, 818 . *** The right of indefinite user (or of using indefinitely) is an essential quality of absolute property, without which absolute property can have no existence. $* * *$ This right of user necessarily includes the right and power of excluding others from using the land. See 2 Austin on Jurisbrudence, 3rd ed.. 836; Wells, J., in Walker v. O.C.W.R.R., 103 Mass., 10, p. 14."

Another useful passage is to be found in the opinion of Sherwood, J., in St. Louis v. Hall :17

"Sometimes the term is applied to the thing itself, as a horse, or a tract of land; these things, however, though the subjects of

${ }^{15}$ (1895) 67 Fed. Rep., 674, 677. For a somewhat similar, and even more confusing, form of statement, see In re Fixei (1900), 102 Fed. Rep., 295, 296.

${ }_{16} 51$ N. H., 504, 511. Se also the excellent similar statements of Comstock, J., in Wynehamer v. People (1856), 13 N. Y., 378, 396; Selden J., S. C., 13 N. Y., 378, 433-434; Ryan, C., in Law v. Rees Printing Co. (1894), 41 Neb., 127,. 146; Magruder, J., in Dixon v. People (1897), 168 I1l., 179, 190.

17 (1893) 116 Mo., 527, 533-534. That the last sentence quoted is not altogether adequate as an analysis of property will appear, it is hoped, from the latter part of the present discussion.

See also, as regards the term, "property," the opinion of Doe, C. J.. in Smith v. Fairloh (1894), 68 N. H., 123, 144-145. ("By considering the property dissolved into the legal rights of which it consists" etc.) 
property, are, when coupled with possession, but the indicia, the visib.e manifestation of invisible rights, 'the evidence of things not seen.'

"Property, then, in a determinate object, is composed of certain constituent elements, to wit: The unrestricted right of use, enjoyment, and disposal, of that object."

In connection with the ambiguities latent in the term "property", it seems well to observe that similar looseness of thought and expression lurks in the supposed (but false) contrast between "corporeal" and "incorporeal" property. The second passage above quoted from Pollock and Maitland exhibits one phase of this matter. For further striking illustration, reference may be made to Blackstone's well-known discussion of corporeal and incorporeal hereditaments. Thus, the great commentator tells us:

"But an hereditament, says Sir Edward Coke, is by much the largest and most comprehensive expression; for it includes not only lands and tenemen's, but whatsoever may be inherited, be it corporeal or incorporeal, real, personal, or mixed."18

It is clear that only legal interests as such can be inherited; yet in the foregoing quotation there is inextricable confusion between the physical or "corporeal" objects and the corresponding legal interests, all of which latter must necessarily be "incorporeal," or "invisible," to use the expression of Mr. Justice Sherwood. This ambiguity of thought and language continues throughout Blackstone's discussion; for a little later he says:

"Hereditaments, then, to use the largest expression, are of two kinds, corporeal and incorporeal. Corporeal consist of such as affect the senses, such as may be seen and handled by the body; incorporeal are not the objects of sensation, can neither be seen nor handled; are creatures of the mind, and exist only in contemplation."

Still further on he says:

"An incorporeal hereditament is a right issuing out of a thing corporate (whether real or personal), or concerning, or annexed to, or exercisable within, the same. ***

"Incorporeal hereditaments are principally of ten sorts: advowsons, tithes, commons, ways, offices, dignities, franchises, corodies or pensions, annuities, and rents."

182 Black. Com. (1765), 16-43. 
Since all legal interests are "incorporeal"-consisting, as they do, of more or less limited aggregates of abstract legal relationssuch a supposed contrast as that sought to be drawn by Blackstone can but serve to mislead the unwary. The legal interest of the fee simple owner of land and the comparatively limited interest of the owner of a "right of way" over such land are alike so far as "incorporeality" is concerned; the true contrast consists, of course, primarily in the fact that the fee simple owner's aggregate of legal relations is far more extensive than the aggregate of the easement owner.

Much of the difficulty, as regards legal terminology, arises from the fact that many of our words were originally applicable only to physical things $;^{19}$ so that their use in connection with legal relations is, strictly speaking, figurative or fictional. The term, "transfer," is a good example. If X says that he has transferred his watch to $\mathrm{Y}$, he may conceivably mean, quite literally, that he has physically handed over the watch to $Y$; or, more likely, that he has "transferred" his legal interest, without any delivery of possession,- the latter, of course, being a relatively figurative use of the term. This point will be reached again, when we come to treat of the "transfer" of legal interests. As another instance of this essentially metaphorical use of a term borrowed from the physical world, the word "power" may be mentioned. In legal discourse, as in daily life, it may frequently be used in the sense of physical or mental capacity to do a thing; but, more usually and aptly, it is used to indicate a "legal power", the connotation of which latter term is fundamentally different. The same observations apply, mutatis mutandis, to the term "liberty."

Passing to the field of contracts, we soon discover a similar inveterate tendency to confuse and blur legal discussions by failing to discriminate between the mental and physical facts involved in the so-called "agreement" of the parties, and the legal "contractual obligation" to which those facts give rise. Such

${ }_{19}$ Compare Poll. \& Maitl. Hist. Eng. Law (2nd ed., 1905), Vol. II. p. 31: "Few, if any, of the terms in our legal vacabulary have always been technical terms. The license that the man of science can allow himself of coining new words is one which by the nature of the case is denied to lawyers. They have to take their terms out of the popular speech; gradually the words so taken are defined; sometimes a word continues to have both a technical meaning for lawyers and a different and vaguar meaning for laymen; sometimes the word that lawyers have adopted is abandoned by the laity." Compare also Ibid., p. 33. 
ambiguity and confusion are peculiarly incident to the use of the term "contract." One moment the word may mean the agreement of the parties; and then, with a rapid and unexpected shift, the writer or speaker may use the term to indicate the contractual obligation created by law as a result of the agrement. Further instances of this sort of ambiguity will be noticed as the discussion proceeds.

OPERATIVE FACTS CONTRASTED WITH EVIDENTIAL FACTS.

For the purpose of subsequent convenient reference, it seems necessary at this point to lay emphasis upon another important distinction inherent in the very nature of things. The facts important in relation to a given jural transaction may be either operative facts or evidential facts. Operative, constitutive, causal, or "dispositive" facts are those which, under the general legal rules that are applicable, suffice to change legal relations, that is, either to create a new relation, or to extinguish an old one, or to perform both of these functions simultaneously. ${ }^{20}$ For

${ }^{20}$ Compare Waldo, C. J., in White v. Multonomah Co. (1886), 13 Ore., 317, 323: "A 'right' has been define dby Mr. Justice Holmes to be the legal consequence which attaches to certain facts. (The Common Law, 214). Every fact which forms one of the group of facts of which the right is the legal consequence appertains to the substance of the right."

The present writer's choice of the term "operative" has been suggested by the following passage from Thayer, Prelim. Treat. Evid. (1898), p. 393: "Another discrimination to be observed is that between documents which constitute a contract, fact, or transaction, and those which merely certify and evidence something outside of themselves, - a something valid and operative, independent of the writing."

Compare also Holland, Jurisp. (10th ed, 1906), 151: "A fact giving rise to a right has long been described as a 'title'; but no such well-worn equivalent can be found for a fact through which a right is transferred, or for one by which a right is extinguished. A new nomenclature was accordingly invented by Bentham, which is convenient for scientific use, although it has not found its way into ordinary language. He describes this whole class of facts as 'Dispositive'; distinguishing as 'Investitive' those by means of which a right comes into existerce, as 'Divestitive' those through which it terminates, and as 'Translative' those through which it passes from one person to another."

The word "ultimate," sometimes used in this connection, does not seem to be so pointed and useful a term as either "operative" or "constitutive." - 
example, in the creation of a contractual obligation between $\mathrm{A}$ and $\mathrm{B}$, the affirmative operative facts are, inter alia, that each of the parties is a human being, that each of them has lived for not less than a certain period of time, (is not "under age"), that $A$ has made an "offer," that B has "accepted" it, etc. It is sometimes necessary to consider, also, what may, from the particular point of view, be regarded as negative operative facts. Thus, e.g., the fact that A did not wilfully misrepresent an important matter to $B$, and the fact that A had not "revoked" his offer, must really be included as parts of the totality of operative facts in the case already put.

Taking another example,-this time from the general field of torts-if $\mathrm{X}$ commits an assault on $\mathrm{Y}$ by putting the latter in fear of bodily harm, this particular group of facts immediately create in $\mathrm{Y}$ the privilege of self-defense,-that is, the privilege of using sufficient force to repel X's attack; or, correlatively, the otherwise existing duty of $\mathrm{Y}$ to refrain from the application of force to the person of $\mathrm{X}$ is, by virtue of the special operative facts, immediately terminated or extinguished.

In passing, it may not be amiss to notice that the term, "facts in issue," is sometimes used in the present connection. If, as is usual, the term means "facts put in issue by the pleadings," the expression is an unfortuante one. The operative facts alleged by the pleadings are more or less generic in character; and if the pleadings be sufficient, only such generic operative facts are "put in issue." The operative facts of real life are, on the other hand, very specific. That being so, it is clear that the real and specific facts finally relied on are comparatively seldom put in issue by the pleadings. Thus, if, in an action of tort, the declaration of $A$ alleges that he was, through the carelessness, etc., of $B$, bitten by the latter's dog, the fact alleged is generic in character, and it matters not whether it was dog Jim or dog Dick that did the biting. Even assuming, therefore, that the biting was done by Jim, (rather than by Dick), it could not be said that this specific fact was put in issue by the pleadings. Similarly, and more obviously, the pleading in an ordinary action involving so-called negligence, is usually very generic in character, ${ }^{21}$ so

21 Compare, however, Illinois Steel Co. v. Ostrowski (1902), 194 Ill., 376, 384, correctly sustaining a declaration alleging the operative facts specifically instead of generically, as required by the more approved forms of pleading. 
that any one of various possible groups of specific operative facts would suffice, so far as the defendant's obligation ex delicto is concerned. It therefore could not be said that any one of such groups had been put in issue by the pleadings. A common fallacy in this connection is to regard the specific operative facts established in a given case as being but "evidence" of the generic (or "ultimate") operative facts alleged in the pleadings. ${ }^{22}$

An evidential fact is one which, on being ascertained, affords some logical basis-not conclusive-for inferring some other fact. The latter may be either a constitutive fact or an intermediate evidential fact. Of all the facts to be ascertained by the tribunal, the operative are, of course, of primary importance; the evidential are subsidiary in their functions. ${ }^{28}$ As a rule there is little danger of confusing evidential facts with operative facts. But there is one type of case that not infrequently gives rise to this sort of error. Suppose that in January last a contractual obligation was created by written agreement passing between $\mathrm{A}$ and $\mathrm{B}$. In an action now pending between these parties, the physical instrament is offered for inspection by the tribunal. If one were thoughtless, he would be apt to say that this is a case where part of the operative facts creating the original obligation are directly presented to the senses of the tribunal. Yet a moment's reflection will show that such is not the case. The document, in its

The rules of pleading determining whether allegations must be generic or specific-and if the latter, to what degree-are, like other rules of law, based an considerations of policy and convenience. Thus the facts constituting fraud are frequently required to be alleged in comparatively specific form; and similarly as regards cruelty in an action for divorce based on that ground. The reasons of policy are obvious in each case.

22 Compare McCaughey v. Schuette (1897), 117 Cal., 223. While the decision in this case can be supported, the statement that the specific facts pleaded were "evidentiary" seems inaccurate and misleading.

There are, of ccurse, genuine instances of the fatally erroneous pleading of strictly evidential facts instead of either generic or specific operative facts. See Rogers $v$. Milwaukee, 13 Wis., 610; and contrast Illinois Steel Co. v. Ostrowski, supra, note 21.

${ }^{23}$ Both operative and evidential facts must, under the law, be ascertained in some one or more of four possible modes: 1. By judicial admissions (what is not disputed); 2. By judicial notice, or knowledge (what is known or easily knowable); 3. By judicial perception (what is ascertained directly through the senses; cf. "real evidence"); 4. By judicial inference (what is ascertained by reasoning from facts already ascertained by one ar more of the four methods here outlined). 
then existing shape, had, as regards its operative effect, spent its force as soon as it was delivered in January last. If, therefore, the unaltered document is produced for inspection, the facts thus ascertained must, as regards the alleged contractual agreement, be purely evidential in character. That is to say, the present existence of the piece of paper, its specific tenor, etc., may, along with other evidential facts (relating to absence of change) tend to prove the various operative facts of last January,--to wit, that such paper existed at that time; that its tenor was then the same as it now is; that it was delivered by $A$ to $B$, and so forth.

It now remains to observe that in many situations a sing'e convenient term is employed to designate (generically) certain miscellaneous groups of operative facts which, though differing widely as to their individual "ingredients," have, as regards a given matter, the same net force and effect. When employed with discrimination, the term "possession" is a word of this character; so also the term "capacity," the term "domicile," etc. But the general tendency to confuse legal and non-legal quantities is manifest here as elsewhere; so that only too frequently these words are used rather nebulously to indicate legal relations as such. ${ }^{24}$

\section{FUNDAMENTAL JURAL RELATIONS CONTRASTED WITH ONE ANOTHER.}

One of the greatest hindrances to the clear understanding, the incisive statement, and the true solution of legal problems frequently arises from the express or tacit assumption that all legal relations may be reduced to "rights" and "duties," and that these latter categories are therefore adequate for the purpose of analyzing even the most complex legal interests, such as trusts, options, escrows, "future"' interests, corporate interests, etc. Even if the difficulty related merely to inadequacy and ambiguity of

24 As an example of this, compare Lord Westbury, in Bell v. Kennedy (1868); L. R. 1 H. L. (Sc.), 307: "Domicile, therefore, is an idea of the law. It is the relation which the law creates between an individual and a particular locality or country."

Contrast the far more accurate language of Chief Justice Shaw, in Abington ข. Bridgewater (1840), 23 Pick., 170: "The fact of domicile is eften one of the highest importance to a persen; it determines his civil and political rights and privileges, duties and obligations. *** 
terminology, its seriousness would nevertheless be worthy of definite recognition and persistent effort toward improvement; for in any closely reasoned problem, whether legal or non-legal, chameleon-hued words are a peril both to clear thought and to lucid expression. ${ }^{25}$ As a matter of fact, however, the above mentioned inadequacy and ambiguity of terms unfortunately reflect, all too often, corresponding paucity and confusion as regards actual legal conceptions. That this is so may appear in some measure from the discussion to follow.

${ }^{25}$ In this connection, the words of one of the great masters of the common law are significant. In his notable Preliminary Treatise on Evidence (1898), p. 190, Professor James Bradley Thayer said:

"As our law develops it becomes more and more important to give" definiteness to its phraseology; discriminations multiply, new situations and complications of fact arise, and the old outfit of ideas, discriminations, and phrases has to be carefully revised. Law is not so unlike all other subjects of human contemplation that clearness of thought will not help us powerfully in grasping it. If terms in common legal use are used exactly, it is well to know it; if they are used inexactly, it is well to know that, and to remark just how they are used."

Perhaps the most characteristic feature of this author's great constructive contribution to the law of evidence is his constant insistence on the need for clarifying our legal terminology, and making careful "dis. criminations" between conceptions and terms that are constantly being treated as if they were one and the same. See, e.g., Ibid., pp. vii, 183, $189-190,278,306,351,355,390-393$. How great the influence of those discriminations has been is well known to all students of the law of evidence.

The comparatively recent remarks of Professor John Chipman Gray, in his Nature and Sources of the Law (1909), Pref. p. viii, are also to the point:

"The student of Jurisprudence is at times troubled by the thought that he is dealing not with things, but with words, that he is busy with the shape and size of counters in a game of logomachy, but when he fully realizes how these words have been passed and are still being passed as money, not only by focls and on fools, but by and on some of the acutest minds, he feels that there is work worthy of being done, if only it can be done worthily."

No less significant and suggestive is the recent and charactistic utterance of one of the greatest jurists of our time, Mr. Justice Hoimes. In Hyde v. United States (1911), 225 U. S., 347, 391, the learned judge very aptly remarked: "It is one of the misfortunes of the law that ideas become encysted in phrases and thereafter for a long time cease to provoke further analysis."

See also, Field, J., in Morgan v. Lonisiana (1876), 93 U. S., 217, 223, and Peckham. J. in Phoenix Ins. Co. v. Tennessee (1895), 161 U. S., 174, 177, 178. 
The strictly fundamental legal relations are, after all, sui generis; and thus it is that attempts at formal definition are always unsatisfactory, if not altogether useless. Accordingly, the most promising line of procedure seems to consist in exhibiting all of the various relations in a scheme of "opposites" and "correlatives," and then proceeding to exemplify their individual scope and application in concrete cases. An effort will be made to pursue this method:

\begin{tabular}{|c|c|c|c|c|}
\hline$\left\{\begin{array}{l}\text { Jural } \\
\text { Upposites }\end{array}\right.$ & $\begin{array}{l}\text { rights } \\
\text { no-rights }\end{array}$ & $\begin{array}{l}\text { privilege } \\
\text { ciuty }\end{array}$ & $\begin{array}{l}\text { power } \\
\text { disability }\end{array}$ & $\begin{array}{l}\text { immunity } \\
\text { liability }\end{array}$ \\
\hline $\begin{array}{l}\text { Jural } \\
\text { Correlatives }\end{array}$ & $\begin{array}{l}\text { right } \\
\text { duty }\end{array}$ & $\begin{array}{l}\text { privilege } \\
\text { no-right }\end{array}$ & $\begin{array}{l}\text { power } \\
\text { liability }\end{array}$ & $\begin{array}{l}\text { immunity } \\
\text { disability }\end{array}$ \\
\hline
\end{tabular}

Rights and Duties. As already intimated, the term "rights" tends to be used indiscriminately to cover what in a given case may be a privilege, a power, or an immunity, rather than a right in the strictest sense; and this looseness of usage is occasionally recognized by the authorities. As said by Mr. Justice Strong in People v. Dikeman:28

"The word 'right' is defined by lexicographers to denote, among other things, property, interest, pozver, prerogative, immunity, privilege (Walker's Dict. word 'Right'). In law it is most frequently applied to property in its restricted sense, but it is often used to designate power, prerogative, and privilege, ***."

Recognition of this ambiguity is also found in the language of Mr. Justice Jackson, in United States v. Patrick: ${ }^{2 \pi}$

“The words 'right' or 'privilege' have, of course, a variety of meanings, according to the connection or context in which they are used. Their definition, as given by standard lexicographers, include 'that which one has a legal claim to do,' 'legal pozver,' 'authority,' 'immunity granted by authority,' 'the investiture with special or peculiar rights." "

And, similarly, in the language of Mr. Justice Sneed, in Lonas v. State $:^{28}$

"The state, then, is forbidden from making and enforcing any law which shall abridge the privileges and immunities of citizens of the United States. It is said that the words rights, privileges and immunities, are abusively used, as if they were synonymous.

26 (1852) 7 How. Pr., 124, 130.

$2 \pi$ (1893) 54 Fed. Rep., 338, 348.

${ }^{28}$ (1871) 3 Heisk. (Tenn.), 287, 306-307. 
The word rig'ts is generic, common, embracing whatever may be lawfully claimed."20

It is interesting to observe, also, that a tendency toward discrimination may be found in a number of important constitutional and statutory provisions. Just how accurate the distinctions in the mind of the draftsman may have been it is, of course, impossible to say. ${ }^{30}$

Recognizing, as we must, the very broad and indiscriminate use of the term, "right," what clue do we find, in ordinary legal discourse, toward limiting the word in question to a definite and appropriate meaning. That clue lies in the correlative "duty," for it is certain that even those who use the word and the conception "right" in the broadest possible way are accustomed to thinking of "duty" as the invariable correlative. As said in Lake Shore \& M. S. R. Co.v. Kurtz: :31

20 See also, for similar judicial observations, Atchison $\mathcal{E}$ Neb. R. Co. v. Baty (1877), $6 \mathrm{Neb}, 37,40$. (The term right in civil society is defined to mean that which a man is entitled to have, or to do, or to receive from others within the limits prescribed by law."); San Francisco v. S. V. Water Co. ( ), $48 \mathrm{Cal}$, 531 ("We are to ascertain the rights, privileges, powers, duties and obligations of the Spring Valley Water Co., by reference to the general law.").

Compare alsc Gilbert, Evid. (4th ed., 1.777), 126: "The men of one county, city, hundred, town, corporation, or parish are evidence in relation. to the rights privileges, immuntities and affairs of such town, city, etc."

${ }^{30}$ See Kearns v. Cordwainers' Co. (1859), 6 C. B. N. S., 388, 4 U9 (construing The Thames Conservancy Act, 1857, 20 and 21 Vict. c. cxlvii., s. 179: "None of the powers by this act conferred $* * *$ shall extend to, take away, alter or abridge any right, claim, privilege, franchise, exemption, or immunity to which any owners $* * *$ of any lands $* * *$ are now by law entitled."); Fearon v. Mitchell (1872), L. R. 7 Q. B., 690, 695 ("The other question remains to be disposed of, as to whether the case comes within the praviso of s. 50 of 21 and 22 Vict. c. 98, that 'no market shall be established in pursuance of this scction so as to interfere with any rights, powers, or privileges enjoyed within the district by any person without his consent." "); Cal. Civ. Code, sec. 648a: "Building and loan associations may be formed under this title with or without guarantee or other capital stock, with all the rights, powers, and privileges, and subject -to all the restrictions and liabilities set forth in this title."); Tenn. Const. of 1834, Art. 9, sec. 7: "The legislature shall have no power to pass any law granting to any individual or individuals, rights, privileges and immunities or exemptions, other than ***”).

31 (1894) 10 Ind. App., 60; 37 N. E., 303, 304. 
"A duty or a legal obligation is that which one ought or ought not to do. 'Duty' and 'right' are correlative terms. When a right is invaded, a duty is violated." 32

In other words, if $\mathrm{X}$ has a right against $\mathrm{Y}$ that he shall stay off the former's land, the correlative (and equivalent) is that $Y$ is under a duty toward $X$ to stay off the place. If, as seems desirable, we should seek a synonym for the term "right" in this limited and proper meaning, perhaps the word "claim" would prove the best. The latter has the advantage of being a monosyllable. In this connection, the language of Lord Watson in Studd v. Cook $^{33}$ is instructive:

"Any words which in a settlement of moveables would be recognize 1 by the law of Scotland as sufficient to create a right or claim in favor of an executor $* * *$ must receive effect if used with reference to lands in Scotland."

Privileges and "No-Rights." As indicated in the above scheme of jural relations, a privilege is the opposite of a futy, and the correlative of a "no-right." In the example last put, whereas $X$ has a right or claim that $\mathrm{Y}$, the other man, should stay off the land, he himself has the privilege of entering on the land; or, in equivalent words, $X$ does not have a duty to stay off. The privilege of entering is the negation of a duty to stay off. As indicated by this case, some caution is necessary at this point, for, always, when it is said that a given privilege is the mere negation of a duty, what is meant, of course, is a duty having a content or tenor precisely opposite to that of the privilege in question. Thus, if, for some special reason, $X$ has contracted with $Y$ to go on the former's own land, it is obvious that $X$ has, as regards $Y$, both the privilege of entering and the duty of entering. The privilege is perfectly consistent with this sort of duty,-

32 See also Howley Park Coal, etc., Co. v. L. \& N.W.Ry. (1913), A. C. 11, 25, 27 (per Viscount Haldane, L. C.: "There is an obligation (of lateral support) on the neighbor, and in that sense there is a correlative right on the part of the owner of the first piece of land;" per Lord Shaw : "There is a reciprocal right to lateral support for their respective lands and a reciprocal obligation upon the part of each owner. $* * *$ No diminution of the right on the one hand or of the cbligation on the other can be effected except as the result of a plain contract. $* * *$ ).

Compare, to similar effect, Galveston, etc. Ry. Co. v. Harrigan (1903), 76 S. W., 452, 453 (Tex. Civ. App.).

83 (1883) 8 App. Cas., at p. 597. 
for the latter is of the same content or tenor as the privilege; but it still holds good that, as regards Y, X's privilege of entering is the precise negation of a duty to stay off. Similarly, if A has not contracted with $B$ to perform certain work for the latter, A's privilege of not doing so is the very negation of a duty of doing so. Here again the duty contrasted is of a content or tenor exactly opposite to that of the privilege.

Passing now to the question of "correlatives," it will be remembered, of course, that a duty is the invariable correlative of that legal relation which is most properly called a right or claim. That being so, if further evidence be needed as to the fundamental and important difference between a right (or claim) and a privilege, surely it is found in the fact that the correlative of the latter relation is a "no-right," there being no single term available to express the latter conception. Thus, the correlative of X's right that $Y$ shall not enter on the land is Y's duty not to enter; but the correlative of $X$ 's privilege of entering himself is manifestly $Y$ 's "no-right" that $\mathrm{X}$ shall not enter.

In view of the considerations thus far emphasized, the importance of keeping the conception of a right (or claim) and the conception of a privilege quite distinct from each other seems evident; and more than that, it is equally clear that there should be a separate term to represent the latter relation. No doubt, as already indicated, it is very common to use the term "right" indiscriminately, even when the relation designated is really that of privilege $;^{34}$ and only too often this identity of terms has involved for the particular speaker or writer a confusion or blurring of ideas. Good instances of this may be found even in unexpected places. Thus Professor Holland, in his work on Jurisprudence, referring to a different and well known sort of ambiguity inherent in the Latin "Ius," the German "Recht," the Italian "Diritto," and the French "Droit,"- -terms used to express "not only 'a right,' but also 'Law' in the abstract,"- -very aptly observes:

"If the expression of widely different ideas by one and the same term resulted only in the necessity for $* * *$ clumsy para-

34 For merely a few out of numberless judicial instances of this loose usage, see Pearce v. Scotcher (1882), L. R. 9 Q. B., 162, 167; Quinn v. Leathem (1901), A. C. 495 (passim); Allen v. Flood (1898), A. C. 1 (passim); Lindley v. Nat. Carbonic Acid Gas Co. (1910), 220 U. S., 61, 75 ; Smith v. Cornell Univ. (1894), 45 N. Y. Supp., 640, 643; Farnum v. Kern Valley Bk. (1910), 107 Pac., 568. See also post, n. 38. 
phrases, or obvious'y inaccurate paraphrases, no great harm would be done; but unfortunately the identity of terms seems irresistibly to suggest an identity between the ideas expressed by them."3s

Curiously enough, however, in the very chapter where this appears, - the chapter on "Rights,"-the notions of right, privilege and power seem to be blended, and that, too, although the learned author states that "the correlative of $* * *$ legal right is legal duty," and that "these pairs of terms express $* * *$ in each case the same state of facts viewed from opposite sides." While the whole chapter must be read in order to appreciate the seriousness of this lack of discrimination a single passage must suffice by way of example:

"If $* * *$ the power of the State will protect him in so carrying out his wishes, and will compel such acts or forbearances on the part of other people as may be necessary in order that his wishes may be so carried out, then he has a 'legal right' so to carry out his wishes." $3 \mathrm{~B}$

The first part of this passage suggests privileges, the middle part rights (or claims), and the last part privileges.

Similar difficulties seem to exist in Professor Gray's able and entertaining work on The Nature and Sources of Law. In his chapter on "Legal Rights and Duties" the distinguished author takes the position that a right always has a duty as its correlative $;^{37}$ and he seems to define the former relation substantially according to the more limited meaning of "claim." Legal privileges, powers, and immunities are prima facie ignored, and the impression conveyed that all legal relations can be comprehended under the conceptions, "right" and "duty." But, with the greatest hesitation and deference, the suggestion may be ventured that a number of his examples seem to show the inadequacy of such mode of treatment. Thus, e.g., he says:

"The eating of shrimp salad is an interest of mine, and, if I can pay for it, the law will protect that interest, and it is therefore a right of mine to eat shrimp salad which I have paid for, although I know that shrimp salad always gives me the colic."38

This passage seems to suggest primarily two classes of relations: first, the party's respective privileges, as against $\mathrm{A}, \mathrm{B}, \mathrm{C}$.

${ }^{85}$ El. Jurisp. (10th ed.), 83.

86 Ibid., 82.

87 See Nat. and Sources of Law (1909), secs. 45, 184.

38 Ibid., sec. 48. 
$D$ and others in relation to eating the salad, or, correlatively, the respective "no-rights" of A. B. C. D and others that the party should not eat the salad; second, the party's respective rights (or claims) as against A. B. C. D and others that they should not interfere with the physical act of eating the salad, or, correlatively, the respective duties of $A, B, C, D$ and others that they should not interfere.

These two groups of relations seem perfectly distinct; and the privileges could, in a given case exist even though the rights mentioned did not. A. B. C. and D, being the owners of the salad, might say to $\mathrm{X}$ : "Eat the salad, if you can; you have our license to do so, but we don't agree not to interfere with you." In such a case the privileges exist, so that if $\mathrm{X}$ succeeds in eating the salad, he has violated no rights of any of the parties. But it is equally clear that if $A$ had succeeded in holding so fast to the dish that $X$ couldn't eat the contents, no right of $X$ would have been violated. ${ }^{39}$

Perhaps the essential character and importance of the distinction can be shown by a slight variation of the facts. Suppose that $X$, being already the legal owner of the salad, contracts with $\mathrm{Y}$ that he $(\mathrm{X})$ will never eat this particular food. With $\mathrm{A}, \mathrm{B}$,

39 Other instances in Professor Gray's work may be noted. In sec. 53, he says: "So again, a householder has the right to eject by force a trespasser from his 'castle.' That is, if sued by the trespasser for an assault, he can call upon the court to refuse the plaintiff its help. In other words, a man's legal rights include not only the power effectually to call for aid from an organized society against another, but also the power to call effectually upon the society to abstain from aiding others."

This, it is respectfully submitted, seems to confuse the householder's privilege of ejecting the trespasser (and the "no-right" of the latter) with a complex of potential rights, privileges, powers and immunities relating to the supposed action at law.

In sec. 102, the same learned author says: "If there is an ordinance that the town constable may kill all dogs without collars, the constable may have a legal right to kill such dogs, but the dogs are not under a legal duty to wear collars."

It would seem, however, that what the ordinance did was to create a privilege-the absence of the duty not to kill which otherwise would have existed in favor of the owner of the dog. Moreover, that appears to be the most natural connotation of the passage. The latter doesn't except very remotely, call up the idea of the constable's accompanying rights against all others that they shouldn't interfere with his actual killing of the dog.

See, alse, secs. $145,186$. 
$C, D$ and others no such contract has been made. One of the relations now existing between $X$ and $Y$ is, as a consequence, fundamentally different from the relation between $X$ and $A$. As regards $Y, X$ has no privilege of eating the salad; but as regards either $A$ or any of the others, $X$ has such a privilege. It is to be observed incidentally that X's right that $Y$ should not eat the food persists even though X's own privilege of doing so has been extinguished. ${ }^{40}$

On grounds already emphasized, it would seem that the line of reasoning pursued by Lord Lindley in the great case of Quinn $v$. Leathem $^{41}$ is deserving of comment:

"The plaintiff had the ordinary rights of the British subject. He was at liberty to earn his living in his own way, provided he did not violate some special law prohibiting him from so doing, and provided he did not infringe the rights of other pzople. This liberty involved the liberty to deal with other persons who were willing to deal with him. This liberty is a right recognized by law; its correlative is the general duty of every one not to prevent the free exercise of this liberty except so far as his own liberty of action may justify him in so doing. But a person's liberty or right to deal with others is nugatory unless they are at liberty to deal with him if they choose to do so. Any interference with their liberty to deal with him affects him."

A "liberty" considered as a legal relation (or "right" in the loose and generic sense of that term) must mean, if it have any definite content at all, precisely the same thing as privilege, ${ }^{42}$ and certainly that is the fair connotation of the term as used the first three times in the passage quoted. It is equally clear, as already indicated, that such a privilege or liberty to deal with others at will might very conceivably exist without any peculiar concomitant rights against "third parties" as regards certain kinds of interference. ${ }^{43}$ Whether there should be such concomitant rights (or claims) is ultimately a question of justice and policy; and it should be considered, as such, on its merits. The only corre'ative logically implied by the privileges or liberties in question are the "no-rights" of "third parties." It would therefore be a non

40 It may be noted incidentally that a statute depriving a party of privileges as such may raise serious constitutional questions under the Fourteenth Amendment. Compare, e.g., Lindley v. Nat. Carbonic Gas Co. (1910), 220 U. S., 61.

41 (1901) A. C., 495, 534.

12 See post, pp. 38-44.

43 Compare Allen v. Flood (1898), A. C., 1. 
sequitur to conclude from the mere existence of such liberties that "third parties." are under a duty not to interfere, etc. Yet in the middle of the above passage from Lord Lindley's opinion there is a sudden and question-begging shift in the use of terms. First, the "liberty" in question is transmuted into a "right," and then, possibly under the seductive influence of the latter word, it is assumed that the "correlative" must be "the general duty of every one not to prevent," etc.

Another interesting and instructive example may be taken from Lord Bowen's oft-quoted opinion in Mogul Steamship Co. $v$. McGregor. ${ }^{44}$

"We are presented in this case with an apparent conflict or antinomy between two rights that are equally regarded by the law-the right of the plaintiffs to be protected in the legitimate exercise of their trade, and the right of the defendants to carry on their business as seems best to them, provided they commit no wrong to others."

As the learned judge states, the conflict or antinomy is only apparent; but this fact seems to be obscured by the very indefinite and rapidly shifting meanings with which the term "right" is used in the above quoted language. Construing the passage as a whole, it seems plain enough that by "the right of the plaintiffs" in relation to the defendants a legal right or claim in the strict sense must be meant; whereas by "the right of the defendants" in relation to the plaintiffs a legal privilege must be intended. . That being so, the "two rights" mentioned in the beginning of the passage, being respectively claim and privilege, could not be in conflict with each other. To the extent that the defendants have privileges the plaintiffs have no rights; and conversely, to the extent that the plaintiffs have rights the defendants have no privileges ("no-privilege" equals duty of opposite tenor)..$^{45}$

44 (1889) 23 Q. B. D., 59.

45 Cases almost without number might be cited to exemplify similar blending of fundamental conceptions and rapid shifting in the use of terms; - and that, too, even when the problems involved have been such as to invite close and careful reasoning. For a few important cases of this character, see Allen v. Flood (1898), A. C, 1, (Hawkins, J., p. 16: "I know it may be asked, "What is the legal right of the plaintiffs which is said to have been invaded?' My answer is, that right which should never be lost sight of, and which I have already stated-the right freely to pursue their lawful calling;" Lord Halsbury, p. 84: "To dig into one's own land 
Thus far it has been assumed that the term "privilege" is the most appropriate and satisfactory to designate the mere negation of duty. Is there good warrant for this?

In Mackeldey's Roman $\mathrm{Law}^{46}$ it is said:

"Positive laws either contain general principles embodied in the rules of law $* * *$ or for especial reasons they estab.ish someth.ing that differs from those general principles. In the first case they contain a common law (jus commune), in the second a special law (jus singulare s. exorbitans). The latter is either favorable or unfavorable $* * *$ according as it enlarges or restr:cts, in cpposition to the common rule, the rights of those for whom it is established. The favorable special law (jus singulare) as also the right created by it *** in the Roman law is termed benefit of the law (bencficium juris) or privilege (privilegium)
$* * *, y_{4}$

First a special law, and then by association of ideas, a special advantage conferred by such a law. With such antecedents, it is not surprising that the English word "privilege" is not infrequently used, even at the present time, in the sense of a special or peculiar legal advantage (whether right, privilege, power or immunity) belonging either to some individual or to some particular class of persons. ${ }^{48}$ There are, indeed, a number of judicial opinions

under the circumstances stated requires no cause or excuse. He may act from mere caprice, but his right on his own land is absolute, so long as he does not interfere with the rights of athers;" Lord Ashbourne, p. 112: "The plaintiff had, in my opinion, a clear right to pursue their lawful calling. *** It would be, I think, an unsatisfactory state of the law that allowed the wilful invader of such a right without lawful leave or justification to escape from the consequences of his action."); Quinn v. Leathem (1901), A. C., 495, 533; Lindsley v. Natural Carbonic Gas Co (1910), 220 U. S., 61, 74; Robertson v. Rochester Folding Box Co. (1902), 171 N. Y., 538 (Parker, C. J., p. 544: "The so-called right of privacy is, as the phrase suggests, founded upon the claim that a man has the right to pass through this world. if he wills, without having his picture published."); Wabash, St. L. \& P. R. Co. v. Shacklet (1883), 105 Ill., 364, 389.

In Purdy v. State (1901), 43 Fla., 538, 540, the anomalous expression "right of privilege" is employed.

46 (Dropsie Tr.) secs. 196-197.

${ }^{47}$ The same matter is put somewhat less clearly in Sohm's Institutes (I.edlies Tr., 3rd ed.), 28.

See also Rector, etc. of Christ Church v. Philadelphia (1860), 24 How., 300, 301, 302.

48 According to an older usage; the term "privilege" was frequently employed to indicate a "franchise." the latter being really a miscellaneous complex of special rights, privileges, powers, or immunities, etc. Thus, in an early book, Termes de la Ley, there is the following definition: "Prrvi- 
recognizing this as one of the meanings of the term in question. ${ }^{4}$ That the. word has a wider signification even in ordinary nontechnical usage is sufficiently indicated, however, by the fact that the term "special privileges" is so often used to indicate a contrast to ordinary or general privileges. More than this, the dominant specific connotation of the term as used in popular speech seems to be more negation of duty. This is manifest in the terse and oft-repeated expression, "That is your privilege,"-meaning, of course, "You are under no duty to do otherwise."

Such being the case, it is not surprising to find, from a wide survey of judicial precedents, that the dominant technical meaning of the term is, similarly, negation of legal duty. ${ }^{\text {so }}$ There are two very common examples of this, relating respectively to "privileged communications" in the law of libel and to "privileges against self-crimination" in the law of evidence. As regards the first case, it is elementary that if a certain group of operative facts are present, a privilege exists, which, without such facts, would not be recognized.5 It is, of course, equally clear that even

leges' are liberties and franchises granted to an office, place, towne, or manor by the King's great charter, letters patent, or Act of Parliament, as toll, sake, socke, infangstheefe, outfangstheefe, turne, or delfe, and divers such like."

Compare Blades $v$ Higgs (1865), 11 H. L. Cas., 621, 631, per Lord Westbury: "Property ratione privilegii is the right which by a peculiar franchise anciently granted by the Crown, by virtue of prerogative, one may have ef taking animals ferae naturae on the land of another; and in like manner the game when taken by virtue of the privilege becomes the absolute property of the owner of the franchise."

${ }^{49}$ See Humplirey $v$. Pegucs (1872), 16 Wall., 244, 247, per Hunt, J.: "All the 'privileges' as well as powers and rights of the prior company. were granted to the latter. A more imporant or more comprehensive privilege than a perpetual immunity from taxation, can scarcely be imagined. It contains the essential idea of a peculiar benefit or advantage, of a special exemption from a burden falling upon others."

See also Smith v. Floyd (1893), 140 N. Y., 337, 342; Lonas v. State (1871). 3 Heisk., 287, 306,307; Territory v Stokes (1881), 2 N. M., 161, 169, 170; Ripley v. Knight (1878), 123 Mass., 515, 519; Dike v. State (1888), 38 Minn., 366; Re Miller (1893), 1 Q. B., 327.

Compare Wisener v. Burrell (1911), 28 Okla., 546.

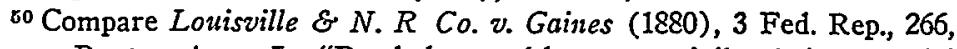
278, per Baxter, Asso. J.: "Paschal says (the term privilege) is a special right belonging to an individual or class; properly, an exemption from some duty."

51 For apt use of the terms, "privilege" and "privileged" in relation to libel, see Hawkins, J., in Allen v. Flood (1898), A. C. 1, 20-21. 
though all such facts be present as last supposed, the superadded fact of malice will, in cases of so-called "conditional privilege," extinguish the privilege that otherwise would exist. It must be evident also, that whenever the privilege does exist, it is not special in the sense of arising from a special law, or of being conferred as a special favor on a particular individual. The same. privilege would exist, by virtue of general rules, for any person whatever under similar circumstances. So, also, in the law of evidence, the privilege against self-crimination signifies the mere negation of a duty, to testify,-a duty which rests upon a witness in relation to all ordinary matters; and, quite obviously, such privilege arises, if at all, only by virtue of general laws. ${ }^{52}$

As already intimated, while both the conception and the term "privilege" find conspicuous exemplification under the law of libel and the law of evidence, they nevertheless have a much wider significance and utility as a matter of judicial usage. To make this clear, a few miscellaneous judicial precedents will now be noticed. In Dowman's Case, ${ }^{53}$ decided in the year 1583, and reported by Coke, the court applied the term to the subject of waste:

"And as to the objection which was made, that the said privilege to be without impeackment of waste cannot be without deed, etc. To that it was answered and resolved, that if it was admitted that a deed in such case should be requisite, yet without question all the estates limited would be good, although it is admitted, that the clause concerning the said privilege would be void."

In the great case of Allen $v$. Flood ${ }^{54}$ the opinion of Mr. Justice Hawkins furnishes a useful passage for the purpose now in view:

52 As regards the general duty to testify, specific performance may usually be had under duress of potential or actual contempt proceedings; and, apart from that, failure to testify might subject the wrongdoer either to a statutory liability for a penalty in favor of the injured party litigant or, in case of actual damage, to a common law action on the case.

The subject of witnesses is usually thought of as a branch of the socalled adjective law, as distinguished, from the so-called substantive law. But, as the writer has had occasion to emphasize on another cccasion (Tre Relations betwen Equity and Law, 11 Mich. L. Rev., 537, 554, 556, 569), there seems to be no intrinsic or essential difference between those jural relations that relate to the "substantive" law and those that relate to the "adjective" law. This matter will be considered more fully in a later part of the discussion.

53 (1583) 9 Coke, 1.

54 (1898) A. C., 1, 19. 
"Every person has a privilege $* * *$ in the interests of public justice to put the criminal law in motion against another whom l.e bona fide, and upon reasonable and probable cause, believes to lave been guilty of a crime. *** It must not, however, be supposed that hatred and ill-will existing in the mind of a prosecutor must of necessity destroy the privilege, for it is not impossible that such hatred and ill-will may have very natural and pardonable reasons for existing. ***⿻

Applying the term in relation to the subject of property, Mr. Justice Foster, of the Supreme Court of Maine, said in the case of Pulitzer v. Lumgston:"5

"It is contrary to the policy of the law that there should be any outstanding titles, estates, or powers, by the existence, operation or exercise of which, at a period of time beyond lives in being and twenty-one years and a fraction thereafter, the complete and unfettered enjoyment of an estate, with all the rights, privileges and pozers incident to ozenership, should be qualified or impeded."

As a final example in the present connection, the language of Baron Alderson in Hilton v. Eckerley ${ }^{\text {is }}$ may be noticed:

"Prima facie it is the privilege of a trader in a free country, in all matters not contrary to law, to regulate his own mode of carrying them on according to his discretion and choice.",57

The closest synonym of legal "privilege" seems to be legal "liberty." This is sufficiently indicated by an unusually discriminating and instructive passage in Mr. Justice Cave's opinion in Allen v. Flood::s

"The personal rights with which we are most familiar are: 1. Rights of reputation; 2. Rights of bodily safety and freedom; 3. Rights of property; or, in other words, rights relating to mind, body and estate, ***

"In my subsequent remarks the word 'right' will, as far as possible, always be used in the above sense; and it is the more

s5 (1896) $89 \mathrm{Me}, 359$.

56 (1856) 6 E. \& B., 47.74.

"57 For other examples of apt use of the term in question, see Borland $v$ Boston (1882), 132 Mass., 89 ("municipal rights, privileges, powers or duties") ; Hamilton $v$. Graham (1871), L. R. 2 H. L. (Sc.), 167, 169, per Hatherley, L. C.; Jones v. De Moss (1911), 151 Ia., 112, 117; Kripp v. Curtis (1886), 71 Cal., 62, 63; Lamer v. Booth (1874), 50 Miss., 411, 413; Weller v. Browu (1911), Cal., ; 117 Pac., 517; Mathews v. People (1903), 202 Ill.. 389, 401 ; Abington \%. North Bridgewater (1840), 23 Pick., 170.

53 (1898) A. C., 1, 29. 
necessary to insist on this as during the argument at your Lordship's bar it was frequently used in a much wider and more indefinite sense. Thus it was said that a man has a perfect right to fire off a gun, when all that was meant, apparently, was that a man has a freedom or liberty to fire off a gun, so long as he does not violate or infringe any one's rights in doing so, which is a very different thing from a right, the violation or disturbance of which can be remedied or prevented by legal process." ${ }^{\prime 6}$

While there are numerous other instances of the apt use of the term "liberty," both in judicial opinions ${ }^{60}$ and in conveyancing

69 For the reference to Mr. Justice Cave's opinion, the present writer is indebted to Salmond's work on Jurisprudence. Citing this case and one other, Starey v. Graham (1899), 1 Q. B., 406, 411, the learned author adopts and uses exclusively the term "liberty" to indicate the opposite of "duty," and apparently overlooks the importance of privilege in the present connection. Curiously enough, moreover, in his separate Treatise on Torts, his discussion of the law of defamation gives no explicit intimation that privilege in relation to that subject represents merely liberty, or "no-duty."

Sir Frederick Pollock, in his volume on Jurisprudence (2nd ed., 1904), 62 , seems in effect to deny that legal liberty represents any true legal relation as such. Thus, he says, inter alia: "The act may be right in the popular and rudimentary sense of not being forbidden, but freedom has not the character of legal right until we consider the risk of unauthorized interference. It is the duty of all of us not to interfere with our neighbors' lawful freedom. This brings the so-called primitive rights into the sphere of legal rule and protection. Sometimes it is thought that lawful power or liberty is different from the right not to be interfered with; but for the reason just given this opinion, though plausible, does not seem correct." Compare also Pollock, Essays in Jurisp. \& Ethics (1882), Ch. I.

It is difficult to see, however, why, as between $X$ and $Y$, the "privilege + no-right" situation is not just as real a jural relation as the precisely opposite "duty + right" relation betwen any two parties. Perhaps the habit of recognizing exclusively the latter as a jural relation springs more or less from the traditional tendency to think of the law as consisting of "commands," or imperative rules. This, however, seems fallacious. A rule of law that permits is just as real as a rule of law that forbids; and, similarly,s aying that the law permitis a given act to $\mathrm{X}$ as between himself and $Y$ predicates just as genuine a legal relation as saying that the law forbids a certain act to $\mathrm{X}$ as between himself and $\mathrm{Y}$. That this is so seems, in some measure, to be confirmed by the fact that the first sort of act would ordinarily be pronounced "lawful," and the second "unlawful." Compare Thomas v. Sorrel (1673), Vaughan, 331, 351.

"o Compare Dow v. Newborough (1728), Comyns, 242 ("For the use is only a liberty to take the profits, but two cannot severally take the profits of the same land, therefare there cannot be an use upon a use." It should be observed that in this and the next case to be cited, along with the liberty 
documents, ${ }^{61}$ it is by no means so common or definite a word as "privilege." The former term is far more likely to be used in the sense of physical or personal freedom (i.e., absence of physical restraint), as distinguished from a legal relation; and very frequently there is the connotation of general political liberty, as distinguished from a particular relation between two definite individuals. Besides all this, the term "privilege" has the advantage of giving us, as a variable, the adjective "privileged". Thus, it is frequently convenient to speak of a privileged act, a privileged transaction, a privileged conveyance, etc.

The term "license", sometimes used as if it were synonymous with "privilege," is not strictly appropriate. This is simply another of those innumerable cases in which the mental and physical facts are so frequently confused with the legal relation which

or privilege there are associated powers and rights, etc.: for instance, the power to acquire a title to the things severed from the realty); Bourne $v$. Taylor (1808), 10 East., 189 (Ellenborough, C. J.): "The second question is whether the replication ought to have traversed the liberty of working the mines. *** The word liberty, too, implies the same thing. It imports, ex vi termini, that it is a privilege to be exercised over another man's estates"); Wickham v. Hawkes (1840), 7 M. \& W., 63, 78-79; Quinn v. Leathem (1901), A. C. 495, 534 (per Lord Lindley: see quotation aent, p. ) ; Pollock v. Farmers' Loan \& Trust Co. (1895), 157 U. S., 429, 652 (per White, J., "rights and liberties"); Mathews v. People (1903), 202 Ill., 389, 401 (Magruder, C. J.: "It is now well settled that the privilege of contracting is both a liberty, and a property right.")..

For legislative use of the term in question, see the Copyright Act, 8 Anne (1709) c. 19 ("Shall have the sole right and liberty of printing each bcok and books for the term of ***").

Like the word "privilege" (see ante p. 38, n. 48), the term "liberty" is occasionally used, especially in the older books, to indicate a franchise, or complex of special rights, privileges, powers, or immunities. Thus in Noy's Maxims (1641) there is this definition: "Liberty is a royal privilege in the hands of a subject;" and, similarly, Blackstone (2 Com. 37) says: "Franchise and liberty are used as synonymous terms; and their definition is, a royal privilege, or branch of the king's prerogative, subsisting in the hands of a subject."

This definition is quoted in S. F. Waterworks v. Schottler (1882), 62 Cal. 69, 106, and Central R. \& Banking Co. v. State (1875), 54 Ga., 401, 409. Compare also Rex v. Halifax \& Co. (1891), 2 Q. B., 263.

e1 Compare Pond v. Bates, 34 L. J. (N. S.), 406 ("With full power and free liberty to sink for, win and work the same, with all liberties, privileges, etc., necessary and convenient," etc.); Hamilton $v$. Graham (1871), L. R. 2 H. L. (Sc.), 166, 167 ; Attersoll v. Stevens (1808), 1 Taunt., 183; Wickham v. Hawker (1840), 7 M. \& W., 63, 78-79. 
they create. Accurately used, "license" is a generic term to indicate a group of operative facts required to create a particular privilege,- this being especially evident when the word is used in the common phrase "leave and license." This point is brought out by a passage from Mr. Justice Adams' opinion in Clifford $v$. O'Neill::2

"A license is merely a permission to do an act which, without such permission, would amount to a trespass $* * *$ nor will the continuous enjoyment of the privilege conferred, for any period of t'me cause it to ripen into a tangible interest in the land affected." "83

Powers and Liabilities. As indicated in the preliminary scheme of jural relations, a legal power (as distinguished, of course, from a mental or physical power) is the opposite of legal disability, and the correlative of legal liability. But what is the intrinsic nature of a legal power as such? Is it possible to analyze the conception represented by this constantly employed and very important term of legal discourse? Too close an analysis might seem metaphysical rather than useful; so that what is here presented is intended only as an approximate explanation sufficient for all practical purposes.

A change in a given legal relation may result (1) from some superadded fact or group of facts not under the volitional control of a human being (or human beings); or (2) from some superadded fact or group of facts which are under the volitional control of one or more human beings. As regards the second class of cases, the person (or persons) whose volitional control is paramount may be said to have the (legal) power to effect the particular change of legal relations that is involved in the problem.

The second class of cases-powers in the technical sense-

62 (1896) 12 App. Div., 17; 42 N. Y. Sup., 607, 609.

63 See, in accord, the oft-quoted passage from Thomas $v$. Sorrell (1673), Vaughan, 331, 351 ("A dispensation or license properly passes no interest, nor alters or transfers property in anything, but only makes an action lawful, which without it had been unlawful. As a license to go beyond the seas, to hunt in a man's park, to come into his house, are only actions, which without license, had been unlawful.").

Compare also Taylor v. Waters (1817), 7 Taunt., 374, 384 ("Those cases abundantly prove that a license to enjoy a beneficial privilege in land may be granted, and, notwithstanding the statue of frauds, without writing." In this case the license (operative facts) is more or less confused with privileges (the legal relation created); Heap v. Hartley (1889), 42 Ch. D., 461, 470. 
must now be further considered. The nearest synonym for any ordinary case seems to be (legal) "ability,"64 - the latter being obviously the opposite of "inability," or "disability." The term "right," so frequently and loosely used in the present connection, is an unfortunate term for the purpose,-a not unusual result being confusion of thought as well as ambiguity of expression. ${ }^{\text {sD }}$ The term "capacity" is equally unfortunate; for, as we have already seen, when used with discrimination, this word denotes a particular group of operative facts, and not a legal relation of any kind.

Many examples of legal powers may readily be given. Thus, $\mathrm{X}$, the owner of ordinary personal property "in a tangible object" has the power to extinguish his own legal interest (rights, powers, immunities, etc.) through that totality of operative facts known as abandonment; and-simultaneously and correlatively-to create in other persons privileges and powers relating to the abandoned object,-e.g., the power to acquire title to the later by appropriating it. ${ }^{68}$ Similarly, $\mathrm{X}$ has the power to transfer his interest to $Y$, - that is, to extinguish his own interest and concomitantly create in $\mathrm{Y}$ a new and corresponding interest. ${ }^{\mathrm{ar}}$ So

o4 Compare Remington v. Parkins (1873), 10 R. I., 550, 553, per Durfee, $J .:$ "A power is an ability to da"

"5 See People v. Dikeman (1852), 7 Howard Pr., 124, 130; and Lonas v. State (1871), 3 Heisk. (Tenn.), 287 ,306-307, quoted ante, p.

See also Mabre $v$. Whittaker (1906), 10 Wash., 656, 663 (Washington Laws of 1871 provided in relation to community property: "The husband shall have the management of all the common property, but shall not have the right to sell or encumber real estate except he shall be joined in the sale or encumbrance by the wife. ***" Per Scott, J.: "Right' in the sense used there means power").

Compare also St. Joseph Fire \& Marine Ins. Co. v. Hanck (1876), $63 \mathrm{Mo}, 112.118$.

Numberless additional instances might be given of the use of the term "right," where the legal quantity involved is really a power rather than a right in the sense of claim.

${ }^{68}$ It is to be noted that abandonment would leave $\mathrm{X}$ himself with precisely the same sort of privileges and powers as any other person.

o7 Compare Wynehamer v. People (1856), 13 N. Y., 378, 396 (Comstock, J.: "I can form no noticn of property which does not include the essential characteristics and attributes with which it is clothed by the laws of society $* * *$ among which are, fundamentally the right of the occupant or owner to use and enjoy (the objects) exclusively, and his absolute power to sell and dispose of them") ; Bartemeyer v: Iowa (1873), 18 Wall., 129,137 (Field, J.: "The right of property in an article involves the power 
also $\mathrm{X}$ has the power to create contractual obligations of various kinds. Agency cases are likewise instructive. By the use of some metaphorical expression such as the Latin, qui facit per alium, facit per se, the true nature of agency relations is only too frequently obscured. The creation of an agency relation involves, inter alia, the grant of legal powers to the so-called agent, and the creation of correlative liabilities in the principal. ${ }^{63}$ That is to say, one party $P$ has the power to create agency powers in another party $A,-$ for example, the power to convey X's property, the power to impose (so-called) contractual obligations on $\mathrm{P}$, the power to discharge a debt, owing to $\mathrm{P}$, the power to "receive" title to property so that it shall vest in $P$, and so forth. In passing, it may be well to observe that the term "authority," so frequently used in agency cases, is very ambiguous and slippery in its connotation. Properly employed in the present connection, the word seems to be an abstract or qualitative term corresponding to the concrete "authorization,"-the latter consisting of a particular group of operative facts taking place between the principal and the agent. All too often, however, the term in question is so used as to blend and confuse these operative facts with the

to sell and dispose of such articles as well as to use and enjoy it"); Low v. Rees Printing Co. (1894), 41 Neb., 127, 146 (Ryan, C.: "Property, in its broad sense, is not the physical thing which may be the subject of ownership, but is the right of dominion, possession, and power of disposition which may be acquired over it.").

Since the power of alienation is frequently one of the fundamental elements of a complex legal interest (or property aggregate), it is obvious that a statute extinguishing such power may, in a given case be unconstitutional as depriving the cwner of property without due process of law. See the cases just cited.

${ }^{68}$ For a leading case exhibiting the nature of agency powers, especially powers "coupled with an interest," see Hunt $v$. Ronsmanier (1883), 8 Wheat., 173, 201.

It is interesting to note that in the German Civil Code the provisions relating to agency are expressed in terms of powers,-ie. g., sec. 168: "The expiration of the power is determined by the legal relations upon which the giving of the power is founded. The power is also revocable in the event of the continuance of the legal relation, unless something different results from the latter."

Incidentally, it may be noticed also, that as a matter of English usage, the term "power of attorney" has, by association of ideas, come to be used to designate the mere operative instrument creating the powers of an agent. 
powers and privileges thereby created in the agent. ${ }^{69}$ A careful discrimination in these particulars would, it is submitted, go far toward clearing up certain problems in the law of agency. ${ }^{70}$

Essentially similar to the powers of agents are powers of appointment in relation to property interests. So, too, the powers of public officers are, intrinsically considered, comparable to those of agents,-for example, the power of a sheriff to sell property under a writ of execution. The power of a donor, in a gift causa mortis, to revoke the gift and divest the title of the donee is another clear example of the legal quantities now being considered ;1 also a pledgee's statutory power of sale. ${ }^{72}$

There are, on the other hand, cases where the true nature of the relations involved has not, perhaps, been so clearly recognized. Thus, in the case of a conditional sale of personality, assuming

69 For exampies of the loose and confusing employment of the term "authority" in agency cases,- and that too, in problems of the conflict af laws requiring the closest reason,-see Pope v. Nickerson (1844), 3 Story, 465, 473, 476, 481, 483; Lloyd $v$ Guibert (1865), 6 B. \& S., 100, 117; King v. Sarria (1877), 69 N. Y., 24, 28, 30-32; Risdon, etc., Works v. Furness (1905), 1 K. B. 304 ; (1906) 1 K. B. 49.

For a criticism of these cases in relation to the present matter, see the writer's article The Individual Liability of Stockholders and the Conflict of Laws (1909), 9 Columb. L. Rev., 492, 512, n. 46, 521, n. 71; 10 Columb. L. Rev., 542-544.

70 The clear understanding and recognition of the agency relation as involving the creation of legal powers may be of crucial importance in many cases,-especially, as already intimated, in regard to problems in the conflict of laws. Besides the cases in the preceding note, two others may be referred to, Milliken $v$. Pratt (1878), 125 Mass., 374, presenting no analysis of the agency problem; and, on the other hand, Freeman's Appeal (1897), 68 Conn., 533, involving a careful analysis of the agency relation by Baldwin, $J$. Led by this analysis to reach a decision essentially opposite to that of the Massachusetts case, the learned judge said, inter alia:

"Such was, in effect, the act by which Mrs. Mitchell undertock to do what she had no legal capacity to do, by making her husband her agent to deliver the guaranty to the bank. He had no more power to make it operative by delivery in Chicago to one of his creditors in Illinois, than he would have had to make it operative by delivery here, had it been drawn in favor of one of his creditors in Connecticut. It is not the place of delivery that controls, but the power of delivery."

${ }^{71}$ See Emery v. Clough (1885), 63 N. H., 552 ("right or power of defeasance").

72 See Hudgens v. Clamberlain (1911), $161 \mathrm{Cal}$, 710, 713, 715. For ancther instance of statutory powers, see Capital, etc., Bk. v. Rhodes (1903), 1 Ch. 631, 655 (powers under registry acts.). 
the vendee's agreement has been fully performed except as to the payment of the last installment and the time for the latter has arrived, what is the interest of such vendee as regards the property? Has he, as so often assumed, merely a contractual right to have title passed to him by consent of the vendor, on final payment being made; or has he, irrespective of the consent of the vendor the power to divest the title of the latter and to acquire a perfect title for himself? Though the language of the cases is not always so clear as it might be, the vendee seems to have precisely that sort of power. ${ }^{\mathrm{i3}}$ Fundamentally considered, the typical escrow transaction in which the performance of conditions is within the volitional control of the grantee, is somewhat similar to the conditional sale of personalty; and, when reduced to its lowest terms, the problem seems easily to be solved in terms of legal powers. Once the "escrow" is formed, the grantor still has the legal title; but the grantee has an irrevocable power to divest that title by performance of certain conditions (i.e., the addition of various operative facts), and concomitantly to vest title in himself. While such power is outstanding, the grantor is,

73 Though the nebulous term "rights" is used by the courts, it is evident that powers are the actual quantities involved.

Thus, in the instructive case of Carpenier $v$. Scott (1881), 13 R. I., 477,479 , the court said, by Matteson, J.: "Under it (the conditional sale) the vendee acquires not only the right of possession and use, but the right to become the absolute owner upon complying with the terms of the contract. These are rights of which no act of the vendor can divest him, and which, in the absence of any stipulation in the contract restraining him, he can transfer by sale or mortgage. Upon performance of the conditions of the sale, the title to the property vests in the vendee, or in the event that he has sold, or mortgaged it, in his vendee, or mortgagee, without further bill of sale. $* * *$ These rights constitute an actual, present interest in the property, which, as we have seen above, is capable of transfer by sale or mortgage."

It is interesting to notice that in the foregoing passage, the term "right" is first used to indicate privileges of possession and use; next the term is employed primarily in the sense of legal power, though possibly there is a partial blending of this idea with that of legal claim, or right (in the narrowest connotation); then the term (in plural form) is used for the third time so as to lump together the vendee's privileges, powers and claims.

For another case indicating in substance the true nature of the vendee's interest, see Christensen $v$. Nelson (1901), 38 Or. 473. 477, 479, indicating, in effect, that the vendee's powers as well as privileges may be transferred to another, and that a proper tender constitutes "the equivalen of payment." 
of course, subject to a correlative liability to have his title divested. ${ }^{.4}$ Similarly, in the case of a conveyance of land in fee simple subject to condition subsequent, after the condition has been performed, the original grantor is commonly said to have a "right of entry." If, however, the problem is analyzed, it will be seen that, as of primary importance, the grantor has two legal quantities, (1) the privilege of entering, and (2) the power, by means of such entry, to divest the estate of the grantee. ${ }^{75}$ The latter's estate endures, subject to the correlative liability of being divested, until such power is actually exercised.76

Passing now to the field of contracts, suppose A mails a letter to $B$ offering to sell the former's land, Whiteacre, to the latter for ten thousand dollars, such letter being duly received. The operative facts thus far mentioned have created a power as regards $\mathrm{B}$ and a correlative liability as regards $\mathrm{A}$. B, by dropping a letter of acceptance in the box, has the power to impose potential or inchoate ${ }^{77}$ obligation ex contractu on $\mathrm{A}$ and himself; and, assuming that the land is worth fifteen thousand dollars, that particular legal quantity - the "power plus liability" relation between $\mathrm{A}$ and $\mathrm{B}$-seems to be worth about five thousnad dollars to $\mathrm{B}$. The liability of $\mathrm{A}$ will continue for a reasonable time unless, in exercise of his power to do so, A previously extinguishes it by that series of operative facts known as "revocation." These last matters are usually described by saying that A's "offer" will "con-

74 See Davis $\%$. Clark (1897), 58 Kan. 100; 48 Pac., 563, 565; Loiter v. Pike (1889), 127 Ill., 287, 326; Welstur v. Trust Co. (1895.), 145 N. Y., 275, 283; Furley v. Palmer (1870), 20 Oh. St., 223, 225.

The proposition that the grantee's power is irrevocable is subject to the qualification that it might possibly be extinguished (or modified pro tanto) as the result of a transaction between the grantor and one having the position of bona fide purchaser, or the equivalent.

It is hardly necessary to add that the courts, instead of analyzing the problem of the escrow in terms of powers, as here indicated, are accustomed to stating the question and deciding it in terms of "delivery," "relation back," "performance of conditions," etc.

${ }^{75}$ In this connection it is worthy of note that Sugden, in his work an Powers (8th ed., 1861) 4, uses, contrary to general practice, the expression, "power of entry for condition broken."

76 For miscellaneous instances of powers, see the good opinions in. Bk. of S. Australia v. Abrahams, L. R. P. C., 265; Barlow v. Ross (1890), 24 Q. B. D., 381, 384.

77 As to "inchoate" obligations, see Frost v. Knight (1872) L. R. 7 Ex. 111 , per Cockburn, C. $\int$. This matter will receive further attention in a later part of the discussion. 
tinue" or "remain open" for a reasonable time, or for the definite time actually specified, unless A previously "withdraws" or "revokes" such offer. ${ }^{78}$ While no doubt, in the great majority of cases no harm results from the use of such expressions, yet these forms of statement seem to represent a blending of non-legal and legal quantities which, in any problem requiring careful reasoning, should preferably be kept distinct. An offer, consiclered as a series of physical and mental operative facts, has spent its force as soon as such series has been completed by the "offeree's receipt." The real question is therefore as to the legal effect, if any, at that moment of time. If the latter consist of B's power and A's correlative liability, manifestly it is those legal relations that "continue" or "remain open" until modified by revocation or other operative facts. What has thus far been said concerning contracts completed by mail would seem to apply, mutatis mutan$d i s$, to every type of contract. Even where the parties are in the presence of each other, the offer creates a liability against the offerer, together with a correlative power in favor of the offeree. The only distinction for present purposes would be in the fact that such power and such liability would expire within a very short period of time.

Perhaps the practical justification for this method of analysis is somewhat greater in relation to the subject of options. In his able work on 'Contacts, ${ }^{79}$ Langdell says :

"If the offerer stipulates that his offer shall remain open for a specified time, the first question is whether such stipulation constitutes a binding contract. $* * *$ When such a stipulation is binding, the further question arises, whether it makes the offer irrevocable. It has been a common opinion that it does, but that is clearly a mistake. $* * *$ An offer is merely one of the elements of a contract; and it is indispensable to the making of a contract that the wills of the contracting parties do, in legal contemplation, concur at the moment of making it. An offer, therefore, which the party making it has no power to revoke, is a legal impos-

${ }^{78}$ Compare Boston R. Co. v. Bartlett (1849), 3 Cush., 225: "Though the writing signed by the defendant was but an offer, and an offer which might be revoked, yet while it remained in force and unrevoked, it was a continuing offer, during the time limited for acceptance, and during the whole of the rest of the time it was an offer every instant; but as soon as it was accepted, it ceased to be an offer merely.

Compare also the forms of statement in Ashley, Contr. (1911), 16 et. seq.

${ }^{79}$ Langdell, Sum. Contr. (2nd ed., 1880), sec. 178. 
sibility. Moreover, if the stipulation should make the offer irrevocable, it would be a contract incapable of being broken; which is also a legal impossibility. The only effect, therefore, of such a stipulation is to give the offeree a claim for damages if the stipulation be broken by revoking the offer." $"$

The foregoing reasoning ignores the fact that an ordinary offer ipso facto creates a legal relation-a legal power and a legal liability,-and that it is this relation (rather than the physical and mental facts constituting the offer) that "remains open." If these points be conceded, there seems no difficulty in recognizing an unilateral option agreement supported by consideration or embodied in a sealed instrument as creating in the optionee an irrevocable power to create, at any time within the period specified, a bilateral obligation as between himself and the giver of the option. Correlatively to that power, there would, of course, be a liability against the option-giver which he himself would have no power to extinguish. The courts seem to have no difficulty in reaching precisely this result as a matter of substance; though their explanations are always in terms of "withdrawal of offer," and similar expressions savoring of physical and mental quantities. ${ }^{81}$

In connection with the powers and liabilities created respectively by an ordinary offer and by an option, it is interesting to consider the liabilities of a person engaged in a "public calling;" for, as it seems, such a party's characteristic position is, one might almost say, intermediate between that of an ordinary contractual

${ }^{80}$ Langdell's a priori premises and specific conclusions have been adopted by a number of other writers on the subject. See, for example, Ashley, Contr. (1911), 25 et seq., R. L. McWilliams, Enforcement of Option Agreements (1913), 1 Calif. Law Rev., 122.

81 For a recent judicial expression on the subject, see $W$. G. Reese Co. v. House (1912), 162 Cal., 740, 745 per Sloss J.: "Where there is a consideration, othe option cannot be withdrawn during the time agreed upon for its duration, while, if there be no consideration the party who has given the option may revoke it at any time before acceptance, even though the time limited has not expired *** such offer, duly accepted, constitutes a contract binding upon both parties and enforceable by either."

See, to the same effect, Linn v. McLean (1885), 80 Ala., 360, 364; O'Brien v. Boland (1896), 166 Mass., 481, 483 (sealed offer).

Most of the cases recognizing the irrevocable power of the optionee have arisen in equitable suits for specific performance; but there seems to be no reason for doubting that the same doctrine should be applied in a common law action for damages. See, in accord, Baker v. Shaw (1912), 68 Wash., 99103 (dicta in an action for damages). 
offerer and that of an option-giver. It has indeed been usual to assert that such a party is (generally speaking) under a present duty to all other parties; but this is believed to be erroneous. Thus, Professor Wyman, in his work on Public Service Companies, ${ }^{82}$ says :

"The duty placed upon every one exercising a public calling is primarily a duty to serve every man who is a member of the pub ic. *** It is somewhat difficult to place this exceptional duty in our legal system. $* * *$ The truth of the matter is that the obligati-n resting up:n one who has undertaken the performance of public duty is sui generis."ss

It is submitted that the learned writer's difficulties arise primarily from a failure to see that the innkeeper, the common carrier and others similarly "holding out" are under present liabilities rather than present duties. Correlativly to those liabilities are the respective powers of the various members of the public. Thus, for example, a travelling member of the public has the legal power, by making proper application and sufficient tender, to impose a duty on the innkeeper to receive him as a guest. For breach of the duty thus created an action would of course lie. It would therefore seem that the innkeeper is, to some extent, like one who had given an option to every travelling member of the public. He differs, as regards net legal effect, only because he can extinguish his present liabilities and the correlative powers of the travelling members of the public by going out of business. Yet, on the other hand, his liabilities are more onerous than that of an ordinary contractual offerer, for he cannot extinguish his liabilities by any simple performance akin to revocation of offer.

As regards all the "legal powers" thus far considered, possibly some caution is necessary. If, for example, we consider the ordinary property owner's power of alienation, it is necessary to distinguish carefully between the legal power, the physical power to do the things necessary for the "exercise" of the legal power, and, finally, the privilege of doing these things-that is, if such privilege does really exist. It may or may not. Thus, if $X$, a landowner, has contracted with $Y$ that the former will not alienate to $Z$, the acts of $X$ necessary to exercise the power of alienating to $Z$ are privileged as between $X$ and every party other than $\mathrm{Y}$; but, obviously, as between $\mathrm{X}$ and $\mathrm{Y}$, the former has nc

82 Secs. 330-333.

83 Compare, to the same effect, Keener, Quasi-Contr. (1893), p. 18. 
privilege of doing the necessary acts; or conversely, he is undet a duty to $\mathrm{Y}$ not to do what is necessary to exercise the power.

In view of what has already been said, very little may suffice concerning a liability as such. The latter, as we have seen, is the correlative of power, and the opposite of immunity (or exemption). While no doubt the term "liability" is often loosely used as a synonym for "duty," or "obligation," it is believed, from an extensive survey of judicial precedents, that the connotation already adopted as most appropriate to the word in question is fully justified. A few cases tending to indicate this will now be noticed. In $M c N e e r$ v. $M c N e e r,{ }^{84} \mathrm{Mr}$. Justice Magruder balanced the conceptions of power and liability as follows:

"So long as she lived, however, his interest in her land lacked those elements of property, such as pozver of disposition and liability to sale on execution which had formerly given it the character of a vested estate."

In Booth v. Commonzerealth, ${ }^{85}$ the court had to construe a Virginia statute providing "that all free white male persons who are twenty-one years of age and not over sixty, shall be liable to serve as jurors, except as hereinafter provided." It is plain that this enactment imposed only a liability and not a duty. It is a liability to have a duty created. The latter would arise only when, in exercise of their powers, the parties litigant and the court officers, had done what was necessary to impose a specific duty to perform the functions of a juror. The language of the court, by Moncure, $J$., is particularly apposite as indicating that liability is the opposite, or negative, of immunity (or exemption):

"The word both expressed and implied is 'liable,' which has a very different meaning from 'qualified $* * *$. It's meaning is 'bound' or 'obliged' ***. A person exempt from serving on juries is not liable to serve, and a person not liable to serve is exempt from serving. The terms seem to be convertible."

A further good example of judicial usage is to be found in Emery v. Clough. ${ }^{86}$ Referring to a gift cansa mortis and the donee's liability to have his already vested interest divested by the donor's exercise of his power of revocation, Mr. Justice Smith said:

"The titie to the gift causa mortis passed by the delivery, defeasible only in the lifetime of the donor, and his death perfects

\footnotetext{
84 (1892) 142 IIl., 388, 397.

85 1861) 16 Grat., $519,525$.

80 (1885) 63 N. H., 552.
} 
the title in the donee by terminating the donor's right or power of defeasance. The property passes from the donor to the donee directly $* * *$ and after his death it is liable to be divested only in favor of the donor's creditors. $* * *$ His right and power ceased with his death."

Perhaps the nearest synonym of "liability" is "subjection" or "responsibility." As regards the latter word, a passage from Mr. Justice Day's opinion in McElfresh v. Kirkendall ${ }^{87}$ is interesting:

"The words 'debt' and 'liability' are.not synonymous, and they are not commonly so understood. As applied to the pecuniary relations of the parties, liability is a term of broader significance than debt. *** Liability is responsibility."

While the term in question has the broad generic connotation already indicated, no doubt it very frequently indicates that specific form of liability (or complex of liabilities) that is correlative to a power (or complex of powers) ${ }^{88}$ vested in a party litigant and the various court officers. Such was held to be the meaning of a certain California statute involved in the case of Lattin v. Gillette. ${ }^{89}$ Said Mr. Justice Harrison:

"The word 'liability' is the condition in which an individual is placed after a breach of his contract, or a violation of any obligation resting upon him. It is defined by Bouvier to be responsibility."

87 (1873) 36 Ia., 224, 226.

88 Compare Attorney General v. Sudeley (1896), 1 Q. B., 354, 359 (per Lord Esher: "What is called a 'right of action' is not the power of bringing an action. Anybcdy can bring an action though he has no right at all."); Kroessin v. Keller (1895), 60 Minn., 372 (per Collins, J.: "The power to bring such actions").

89 (1892) 95 Cal., 317, 319.

${ }^{\circ 0} \mathrm{We}$ are apt to think of liability as exclusively an onerous relation of one party to another. But, in its broad technical significance, this is not necessarily so. Thus $\mathrm{X}$, the owner of a watch, has the power to abandon his property-that is, to extinguish his existing rights, powers, and immunities relating thereto (not, however, his privileges, for until someone else has acquired title to the abandoned watch, $\mathrm{X}$ would have the same privileges as before); and correlatively to $X$ 's power of abandonment there is a liability in every other person. But such a liability instead of being onerous or unwelcome, is quite the opposite. As regards another person $M$, for example, it is a liability to have created in his favor (though against his will) a privilege and a power relating to the watch,- that is, the privilege of taking possession and the power, by doing so, to vest a title in himself. See Dougherty v. Creary (1866), 30 Cal., 290, 298. Contrast with this agreeable form of liability the liability to have a duty crealed-for example the liability of one who has made or given an option in a case where the value of the property has greatly risen. 
Immunities and Disabilities. As already brought out, immunity is the correlative of disability ("no-power"), and the opposite, or negation, of liability. Perhaps it will also be plain, from the preliminary outline and from the discussion down to this point, that a power bears the same general contrast to an immunity that a right does to a privilege. A right is one's affirmative claim against another, and a privilege is one's freedom from the right or claim of another. Similarly, a power is one's affirmative "control" over a given legal relation as against another; whereas an immunity is one's freedom from the legal power or "control" of another as regards some legal relation.

A few examples may serve to make this clear. $X$, a landowner, has, as we have seen, power to alienate to $Y$ or to any other ordinary party. On the other hand, $X$ has also various immunities as against $Y$, and all other ordinary parties. For $Y$ is under a disability (i.e., has no power) so far as shifting the legal interest either to himself or to a third party is concerned; and what is true of $Y$ applies similarly to every one else who has not by virtue of special operative facts acquired a power to alienate X's property. If, indeed, a sheriff has been duly empowered by a writ of execution to sell X's interest, that is a very different matter: correlative to such sheriff's power would be the liability of $\mathrm{X}$, - the very opposite of immunity (or exemption). It is elementary, too, that as against the sheriff, $\mathrm{X}$ might be immune or exempt in relation to certain parcels of property, and be liable as to others. Similarly, if an agent has been duly appointed by $X$ to sell a given piece of property, then, as to the latter, $X$ has, in relation to such agent, a liability rather than an immunity.

For over a century there has been, in this country, a great deal of important litigation involving immunities from powers of taxation. If there be any lingering misgivings as to the "practical" importance of accuracy and discrimination in legal conceptions and legal terms, perhaps some of such doubts would be dispelled by considering the numerous cases on valuable taxation exemptions coming before the United States Supreme Court. Thus, in Phoenix Ins. Co. v. Tennessee, ${ }^{91} \mathrm{Mr}$. Justice Peckham expressed the views of the court as follows:

"In granting to the De Sota Company 'all the rights, privileges, and immunities' of the Bluff City Company, all words are used which could be regarded as necessary to carry the exemption from

01 (1895) 161 U. S., 174, 177. 
taxation possessed by the Bluff City Company; while in the next following grant, that of the charter of the plaintiff in error, the word 'immunity' is omitted. Is there any meaning to be attached to that omission, and if so, what? We think some meaning is to be attached to it. The word 'immunity' expresses more clearly and definitely an intention to include therein an exemption from taxation than does either of the other words. Exemption from taxation is more accurately described as an 'immunity' than as a privilege, although it is not to be denied that the latter word may sometimes and under some circumstances include such exemptions.".

In Morgan $v$. Louisiana, ${ }^{92}$ there is an instructive discussion from the pen of $\mathrm{Mr}$. Justice Field. In holding that on a foreclosure sale of the franchise and property of a railroad corporation an immunity from taxation did not pass to the purchaser, the learned Judge said:

"As has been often said by this court, the whole community is interested in retaining the power of taxation undiminished $* * *$. The exemption of the property of the company from taxation; and the exemption of its officers and servants from jury and military duty, were both intended for the benefit of the company, and its benefit alone. In their personal character they are analogous to exemptions from execution of certain property of debtors, made by laws of several of the states." ${ }^{\prime 3}$

' 92 (1876) 93 U. S., 217, 222.

${ }_{93}$ See, in accord, Picard v. Tennessee, etc., R. Co. (1888), 130 U. S., 637, 642, (Field, J.) ; Rochester Railway Co. v. Rochester (1906) 205 U. S., 236, 252 (Moody, J., reviewing the many other cases on the subject).

In Internat. \& G. N. Ry. Co. v. State (1899), 75 Tex., 356, a different view was taken as to the alienability of an immunity from taxation. Speaking by Stayton, C. J., the court said:

"Looking at the provisions of the Act of March 10,1875, we think there can be no doubt the exemption from taxation given by it, instead of being a right vesting only in appellant, is a right which inheres in the property to which it applies, and follows it into the hands of whosover becomes the owner. $* * *$ The existence of this right enharces the value of the property to which it applies. Shareholders and creditors must be presumed to have dealt with the corporation on the faith of the contract which gave the exemption, and it cannot be taken away by legislation, by dissolution of the corporation, or in any ather manner not sufficient to pass title to any other property from one person to another. The right to exemption from taxation is secured by the same guaranty which secures titles to those owning lands granted under the act, and though the corporation may be dissolved, will continue to exist in favor of persons owning the property to which the immunity applies. Lawful dissolution of a corporation will destroy all its corporate franchises or privileges vested by 
So far as immunities are concerned the two judicial discussions last quoted concern respectively problems of interpretation and problems of alienability. In many other cases difficult constitutional questions have arisen as the result of statutes impairing or extending various kinds of immunities. Litigants have, from time to time, had occasion to appeal both to the clause against impairment of the obligation of contracts and to the provision. against depriving a person of property without due process of law. This has been especially true as regards exemptions from taxation $^{94}$ and exemptions from execution. ${ }^{95}$

If a word may now be permitted with respect to mere terms as such, the first thing to note is that the word "right" is overworked in the field of immunities as elsewhere. ${ }^{96}$ As indicated, however, by the judicial expressions already quoted, the best synonym is, of course, the term "exemption." It is instructive legislature not to grant the benefit claimed by the bill."

the act of incorporation; but if it holds rights, privileges, and franchises in the nature of property, secured by contract based on valuable consideration, these will survive the dissolution of the corporation, for the benefit of those who may have a right to or just claim upon its assets."

Compare, as regard homestead exemptiors, Sloss, J., in Smith v. Bougham (1909), 156 Cal., 359, 365: "A declaration of homestead *** attaches certain privileges and immunities to such title as may at the time be held."

${ }^{94}$ See Choate v. Trapp (1912), 224 U. S., 665.

95 See Brearly School, Linited $v$. Ward (1911), 201 N. Y., 358; 94 N. E., 1001 (an interesting decision, with three judges dissenting). The other cases on the subject are collected in Ann. Cas., 1912 B, 259.

${ }^{\circ} \mathrm{S}$ See Brearly School, Limited v. Ward, cited in preceding note; also Internat. \& $G$. $N$. Ry. Co. v. State (1899), 75 Tex., 356, quoted from, ante, n. 91.

97 Compare also Wilson v. Gaines (1877), 9 Baxt. (Tenn.), 546, 550551, Turney, J.: "The use in the statutes of two only of the words of the constitution, i.e., 'rights' and 'privileges,' and the omission to employ either of the other two following in immediate succession, viz., immunities' and 'exemptions,' either of which would have made clear the construction claimed by complainant, evidence a purposed intention on the part of the

Only very rarely is a court found seeking to draw a subtle distinction between an immunity and an exemption. Thus, in a recent case, Strahan z. Wayne Co. (June, 1913), 142 N. W., 678, 680 (Neb.), Mr. Justice Barnes said: "It has been held by the great weight of authority that dower is not immune (from the inheritance tax) because it is dower, but because it $* * *$ belonged to her unchoately during (the husband's) life. *** Strictly speaking, the widcw's share should be considered as immune, rather than exempt, from an inheritance tax. It is free, rather than freed, from such tax." 
to note, also, that the word "impunity" has a very similar connotation. This is made evident by the interesting discriminations of Lord Chancellor Finch in Skelton $v$. Skelton, ${ }^{08}$ a case decided in 1677:

"But this I would by no means allow, that equity should enlarge the restraints of the disabilities introduced by act of parliament; and as to the granting of injunctions to stay waste, I took a distinction where the tenant hath only impunitatem, and where he hath jus in arboribus. If the tenant have only a bare indemnity or exemption from an action (at law), if he committed waste, there it is fit he should be restrained by injunction from committing it."

In the latter part of the preceding discussion, eight conceptions of the law have been analyzed and compared in some detail, the purpose having been to exhibit not only their intrinsic meaning and scope, but also their relations to one another and the methods by which they are applied, in judicial reasoning, to the solution of concrete problems of litigation. Before concluding this branch of the discussion a general suggestion may be ventured as to the great practical importance of a clear appreciation of the distinctions and discriminations set forth. If a homely metaphor be permitted, these eight conceptions,-rights and duties, privileges and no-rights, powers and liabilities, immunities and disabilities,seem to be what may be called "the lowest common denominators of the law." Ten fractions (1-3, 2-5, etc.) may, superficially, seem so different from one another as to defy comparison. If, however, they are expressed in terms of their lowest common denominators (5-15, 6-15, etc.), comparison becomes easy, and fundamental similarity may be discovered. The same thing is

98 (1677) 2 Swanst., 170.

${ }^{90}$ In Skelton $v$. Skelton, it will be observed, the word "impunity" and the word "exemption" are used as the opposite of liability to the powers of a plaintiff in an action at law.

For similar recent instances, see Vacher \& Sons, Limited v. London Society of Compositors (1913), A. C. 107, 118, 125 (per Lord Macnaghten: "Now there is nothing absurd in the notion of an association or body enjoying immunity from actions at law ;" per Lord Atkinson: "Conferring on the trustees immunity as absolute," etc.).

Compare also Baylies v. Bishop of London (1913), 1 Ch., 127, 139, 140, per Hamilton, L. J.

For instances of the apt use of the term "disability" as equivalent to the negation of legal power, see Poury v. Hordern (1900), 1 Ch., 492, 495 ; Sheridan v. Elden (1862), 24 N. Y., 281, 384. 
of course true as regards the lowest generic conceptions to which any and all "legal quantities" may be reduced.

Reverting, for example, to the subject powers, it might be difficult at first glance to discover any essential and fundamental similarity between conditional sales of personalty, escrov: transactions, option agreements, agency relations, powers of appointment, etc. But if all these relations are reduced to their lowest generic terms, the conceptions of legal power and legal liability are seen to be dominantly, though not exclusively, applicable throughout the series. By such a process it becomes possible not only to discover essential similarities and illuminating analogies in the midst of what appears superficially to be infinite and hopeless variety, but also to discern common principles of justice and policy underlying the various jural problems involved. An indirect, yet very practical, consequence is that it frequently becomes feasible, by virtue of such analysis, to use as persuasive authorities judicial precedents that might otherwise seem altogether irrelevant. If this point be valid with respect to powers, it would seem to be equally so as regards all of the other basic conceptions of the law. In short, the deeper the analysis, the great become one's perception of fundamental unity and harmony in the law. ${ }^{100}$

Stanford University, California.

Wesley Nerucomb Hohfeld.

100 The next article in the present series will discuss the distinctions between legal and equitable jural relations; also the contrast between rights, etc., in rem, and rights, etc., in personam. The supposed distinctions betwen substantive and adjective jural relations will also be considered,-chiefly with the purpose of showing that, so far as the intrinsic and essential nature of those relations is concerned, the distinctions commonly assumed to exist are imaginary rather than real. Finally, some attention will be given to the nature and analysis of complex legal interests, or aggregates of jural relations. 